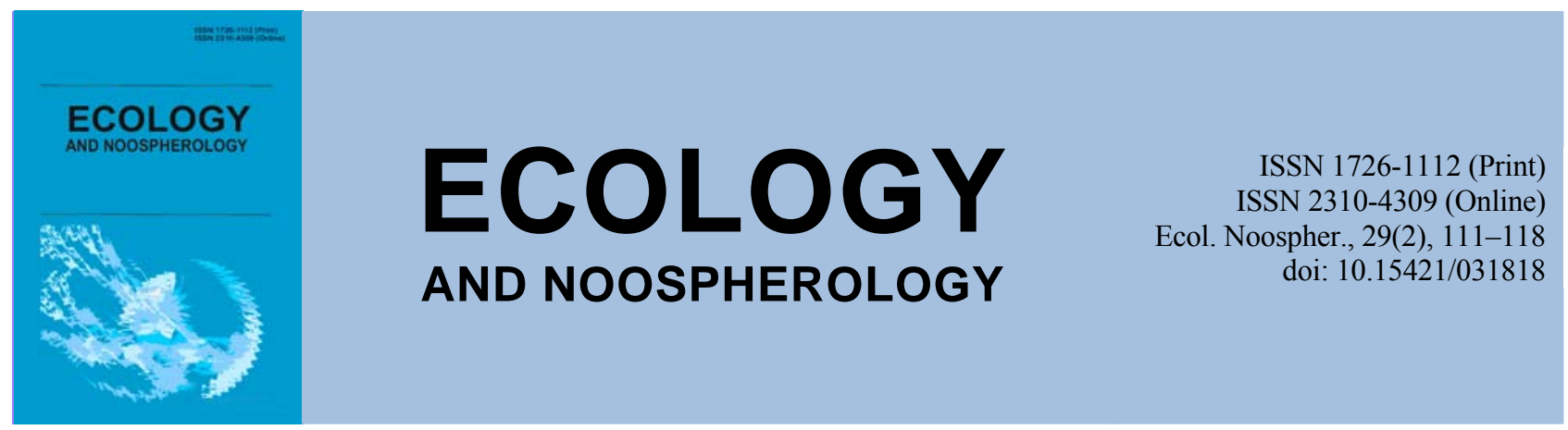

\title{
Diagnostics of lithic discontinuity of soils based on fractal properties of coarse/fine-related distribution
}

\author{
V. M. Yakovenko, A. V. Kotovich \\ Oles Honchar Dnipro National University, Dnipro, Ukraine
}

Article info

Received 15.10.2018

Received in revised form

22.10 .2018

Accepted 27.10.2018

Oles Honchar Dnipro

National University

Gagarin Ave., 72, Dnipro,

49010, Ukraine.

Tel.: +38-066-559-68-06

E-mail: yakovenko_v@i.ua
Yakovenko, V. M., \& Kotovich, A. V. (2018). Diagnostics of lithic discontinuity of soils based on fractal properties of coarse/fine-related distribution. Ecology and Noospherology, 29(2), 111-118. doi:10.15421/031818

In the study of soil genesis and the determination of their systematic position, the diagnosis of the lithological heterogeneity of the parent rock is important. In the World Reference Base of Soil Resources (IUSS Working Group WRB 2015) lithological heterogeneity is defined as significant changes in the particle size or mineralogical composition, which reflect the lithological differences within the soil profile and a number of diagnostic criteria for lithological heterogeneity are given. At the level of soil microstructure, these are the characteristics of the relative distribution of coarse and fine particles of the solid phase ( $\mathrm{c} / \mathrm{f}$ relative distribution). Using the example of forest soils formed on colluvial sediments, we consider the possibility of using the fractal properties of the $\mathrm{c} / \mathrm{f}$ relative distribution to diagnose the lithological heterogeneity of the genetic profile of the soil and establish the contrast of such heterogeneity. A micromorphological study of the soils formed on the parent rocks of loamy and clay granulometric composition reveals the fractal structure of the relative distribution of coarse and fine particles, which is the quantitative and qualitative characteristic of the solid phase and is not recognized by the particle size analysis. In the study with different magnifications, the multilevel structure of the $\mathrm{c} / \mathrm{f}$ of the relative distribution is manifested in the possibility of selecting not one, but several $\mathrm{c} / \mathrm{f}$ thresholds with corresponding characteristics for each. It is important that the overall picture of the microstructure at each level of the $\mathrm{c} / \mathrm{f}$ of the relative distribution is similar to the picture at other levels. The algorithm for studying the fractal properties of the relative distribution is made up of successive stages: revealing the presence of the fractal structure of the $\mathrm{c} / \mathrm{f}$ relative distribution; determination of similarity levels; determination of the morphometric parameters of the relative distribution at each of the revealed levels of similarity, which include the $\mathrm{c} / \mathrm{f}$ threshold, the dimension of the coarse fraction, $\mathrm{c} / \mathrm{f}$ ratio. An additional parameter is the spatial distribution of coarse particles at each level. The studied forest soils of the Prysamaria are characterized by a three-level fractal structure of the organization of the relative distribution of the granulometric elements of the microstructure. At each of the levels of relative distribution, the pattern of microstructure is similar to the levels highlighted in other scales. It was revealed that the profile of Luvic Chernic Phaeozem on the slope of the beam is lithologically inhomogeneous. Subsoil horizons outside the genetic profile of the soil differ in morphometric parameters at the second and third levels of the relative distribution of coarse and fine particles.

\section{Діагностика літологічної неоднорідності грунтів за фрактальними властивостями відносного розподілу грубо- та тонкодисперсних часток твердої фази}

\author{
В. М. Яковенко, О. В. Котович
}

\section{Дніпровський національний університет імені Олеся Гончара, Дніпро, Україна}

Показано, що при мікроморфологічному дослідженні грунтів, сформованих на материнських породах суглинкового та глинистого гранулометричного складу, виявляється фрактальна структура відносного розподілу грубо- та тонкодисперсних 
часток (гд/тд відносний розподіл), що поєднує в собі кількісну та якісну характеристику твердої фази і не розпізнається гранулометричним аналізом. Запропоновано використання фрактальних властивостей гд/тд відносного розподілу для діагностики літологічної неоднорідності генетичного профілю грунтів та встановлення контрастності такої неоднорідності. 3'ясовано, що досліджені лісові грунти Присамар'я характеризуються трирівневою фрактальною структурою організації відносного розподілу гранулометричних елементів мікробудови. На кожному з рівнів відносного розподілу картина мікробудови подібна до рівнів, виділених в інших масштабах.

Ключові слова: мікроморфологія грунтів; рівні подібності; гд/тд поріг; гд/тд співвідношення

\section{Вступ}

При дослідженні генезису грунтів та визначенні їх систематичного положення суттєве значення має діагностика літологічної неоднорідності материнської породи. У Світовій реферативній базі грунтових ресурсів (IUSS Working Group WRB 2015) наведено ряд діагностичних критеріїв літологічної неоднорідності, яка визначається як суттєві зміни у гранулометричному або мінералогічному складі, що відображають літологічні відмінності в межах профілю грунту.

На рівні мікробудови грунтів такими $є$ характеристики відносного розподілу грубо- та тонкодисперсних часток твердої фази (елементарна мікробудова за Парфеновою та Яриловою (Parfyonova, Yarilova, 1977). Встановлення порогу розмірності між грубо- та тонкодисперсними частками залежить від гранулометричного складу і може суттєво варіювати у різних грунтах або частинах профілю у випадку наявності літологічної неоднорідності (Gerasimova et al., 1992; Stoops, 2003).

При дослідженні з різним збільшенням суглинкових $\mathrm{i}$ глинистих за гранулометричним складом грунтів і порід виявляється багаторівнева структура гд/тд відносного розподілу, шо проявляється у можливості виділення не одного, а декількох гд/тд порогів 3 відповідними для кожного характеристиками. Важливо, що загальна картина мікробудови на кожному 3 рівнів гд/тд відносного розподілу $\epsilon$ подібною до картини інших рівнів. Такі особливості мікроморфологічної організації відповідають визначенню фрактальних структур для різних природних об'єктів (Mandelbrot, 1982; Feder, 1991; Bozhokin, Parshin, 2001; Morozov, 2002).

У нашій роботі на прикладі лісових байрачних грунтів розглядається можливість використання для діагностики літологічної неоднорідності профілю суглинкових грунтів фрактальних властивостей відносного розподілу грубо- та тонкодисперсних часток твердої фази.

Профіль лісових грунтів байрачних екосистем Степового Придніпров'я формується в динамічних умовах, під впливом складного комплексу факторів. Серед основних процесів, які формують тип будови генетичного профілю та морфологічні властивості лісових грунтів, виділяється процес транспортування та відкладення делювіального матеріалу в ерозійних елементах мезорельєфу. Внаслідок таких процесів грунтоутворюючими породами байрачних грунтів $є$ делювіальні відклади різної потужності на поверхнях ерозійного походження. Текстурна диференціація профілю внаслідок лесиважу додатково ускладнює загальну картину морфологічної будови лісових грунтів.

Тому для діагностики і розуміння генезису лісових грунтів на делювіальних відкладах важливим $\epsilon$ встановлення літологічної неоднорідності генетичного профілю на основі критеріїв переходу між літологічно відмінними частинами профілю та контрастністю таких переходів.

\section{Матеріали та методи досліджень}

Дослідження проводились у Новомосковському районі Дніпропетровської області на Присамар'і, що є частиною Степового Придніпров'я. Територія району інтенсивно використовується в сільськогосподарському виробництві, тому степова рослинність зберігається лише на не придатних для обробітку грунту ділянках, зокрема на схилах балок та байраків. Лісова рослинність представлена байрачними, заплавними та аренними лісами. Основні породи - дуб звичайний (Quercus robur L.), липа серцелиста (Tilia cordata Mill.), ясен звичайний (Fraxinus exelsior L.), клен польовий (Acer campestre L.), в'яз граболистий (Ulmus minor Mill.), клен гостролистий (Acer platanoides L.), сосна звичайна (Pinus sylvestris L.).

Досліджені грунтові розрізи закладені у верхів”і байраку Глибокого на схилі південної експозиції, який знаходиться на плакорній частині привододільнобалкового ландшафту у 2 км на північ від с. Андріївки. Катена представлена трьома типовими розрізами грунтів на степовій цілині між полем та узліссям (ПП 115-В), середній третині схилу (ПП 111-В) і тальвезі (ПП 109-В) байраку (табл. 1). Характеристика екологічних умов грунтоутворення та повна макроморфологічна характеристика профілів грунтів наведена в роботах Yakovenko (2014) та Yakovenko, Bilova (2015).

Характеристика умов зволоження визначалась за Л. П. Травлєєвим (Travleev, 1977), генетичний тип будови профілю грунтів - за Б. Г. Розановим (Rozanov, 2004). У роботі застосовується класифікація грунтів за WRB (IUSS Working Group WRB, 2015) і номенклатура грунтів, уживана в працях Комплексної експедиції Дніпровського національного університету 3 вивчення природних та штучних лісів степової зони України. Зразки непорушеної будови для мікроморфологічних досліджень відбирались за генетичними горизонтами грунтів, зразки підгрунтових горизонтів відбирались із використанням грунтового бура. Виготовлення прозорих шліфів відбувалось із використанням натуральних смол (Добровольский, 1983).

Визначення типу гд/тд відносного розподілу проводилось за Stoops (2003), мікроморфометричні вимірювання розмірів мінеральних зерен та вмісту скелетної частини мікробудови проводились за Е. I. Гагаріною (Gagarina, 2004). Фотоматеріали отримані з використанням цифрової фотокамери еTREK DCM320.

\section{Результати та їх обговорення}

У районі досліджень широко розвинені процеси водної ерозії розораних територій навколо байраків. Особливо цьому сприяють літні зливи, притаманні для степової зоні. У результаті байрачні екосистеми в районі досліджень акумулюють значні відклади делювіального матеріалу, а території, прилеглі до узлісь байраків, є зоною транзиту делювіальних потоків з більш віддалених територій.

Морфологічна будова грунтів катени відображає особливості динамічних екологічних умов байрачного грунтогенезу.

Чорноземи звичайні (Calcic Chernozem) поблизу узлісся (ПП 115-В) знаходяться в умовах атмосфернотранзитного припливно-відпливного зволоження. Тип будови профілю нормальний, з ознаками змитості частини поверхневого горизонту: $\mathrm{H}_{0}(3,5-0$ см) - повсть 3 переплетених між собою живих і відмерлих трав; Hdk

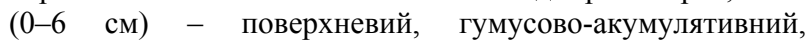
дерновий, середньосуглинковий, карбонатний горизонт; Hpk (6-27 см) - перший перехідний середньосуглинковий, карбонатний горизонт; Phk (27-40 cм) - другий перехідний важкосуглинковий, карбонатний горизонт; Pk (40-120 cм) материнська порода - карбонатний глинистий лес. 
Таблиця 1

Характеристика місць досліджень і класифікація грунтових профілів

\begin{tabular}{|c|c|c|c|c|}
\hline Профіль & Місцезнаходження & $\begin{array}{c}\text { Форма } \\
\text { рельєфу }\end{array}$ & Рослинність & Класифікація* \\
\hline ПП 115-В & $\begin{array}{l}48^{\circ} 47^{\prime} 19.1^{\prime \prime} \mathrm{N} \\
035^{\circ} 27^{\prime} 19.5^{\prime \prime} \mathrm{E} \\
114 \text { м над рівнем моря }\end{array}$ & $\begin{array}{l}\text { Схил } 3^{\circ}, \\
\text { експозиція } \\
\text { південна }\end{array}$ & $\begin{array}{l}\text { Festuca valesiaca Schleich } \\
\text { Poa angustifolia } L . \\
\text { Poa nemoralis } L . \\
\text { Lathyrus tuberosus } L . \\
\text { Achillea millefolium L. } \\
\text { Salvia nemorosa L. }\end{array}$ & $\begin{array}{l}\text { Чорнозем звичайний / } \\
\text { Calcic Chernozem (Loamic, } \\
\text { Tonguic) }\end{array}$ \\
\hline ПП 111-В & $\begin{array}{l}48^{\circ} 47^{\prime} 19.1^{\prime \prime} \mathrm{N} \\
035^{\circ} 27^{\prime} 19.5^{\prime \prime} \mathrm{E} \\
88 \text { м над рівнем моря }\end{array}$ & $\begin{array}{l}\text { Схил } 14^{\circ}, \\
\text { експозиція } \\
\text { південна }\end{array}$ & $\begin{array}{l}\text { Fraxinus exelsior } L . \\
\text { Acer campestre } L . \\
\text { Ulmus minor Mill. } \\
\text { Tilia cordata Mill, } \\
\text { Acer platanoides } L . \\
\end{array}$ & $\begin{array}{l}\text { Чорнозем лісовий / Luvic } \\
\text { Chernic Phaeozem } \\
\text { (Colluvic, Loamic, Pachic) }\end{array}$ \\
\hline ПП 109-В & $\begin{array}{l}48^{\circ} 47^{\prime} 17.5^{\prime \prime} \mathrm{N} \\
035^{\circ} 27^{\prime} 16.5^{\prime \prime} \mathrm{E} \\
76 \text { м над рівнем моря }\end{array}$ & Тальвег & $\begin{array}{l}\text { Quercus robur } L . \\
\text { Fraxinus exelsior } L . \\
\text { Acer campestre } L . \\
\text { Ulmus minor Mill. } \\
\text { Tilia cordata Mill, } \\
\text { Acer platanoides } L .\end{array}$ & $\begin{array}{l}\text { Лучно-чорноземний грунт } \\
\text { / Luvic Gleyic Chernic } \\
\text { Phaeozem (Colluvic, } \\
\text { Loamic, Pachic) }\end{array}$ \\
\hline
\end{tabular}

* Класифікація грунтів: за номенклатурою Комплексної еспедиції ДНУ / відповідно до WRB (2015).

Чорноземи лісові (Luvic Chernic Phaeozem) на схилах (ПП 111-В) формуються в умовах атмосферно-транзитного припливно-відпливного зволоження на делювіальних гумусованих відкладах суглинкового гранулометричного складу. Тип будови профілю поліциклічний: $\mathrm{H}_{0}(2-0 \mathrm{~cm})-$ лісова підстилка 3 листя різного ступеня розкладення; $\mathrm{H}_{1} \mathrm{el}(0-9$ см) - поверхневий гумусово-акумулятивний елювіальний лесивований легкосуглинковий горизонт; $\mathrm{H}_{2} \mathrm{el}$ (9-46 см) - другий гумусово-акумулятивний елювіальний лесивований важкосуглинковий горизонт; $\mathrm{H}_{3} \mathrm{el}$ (46-88 cм) - третій гумусово-акумулятивний елювіальний лесивований глинистий горизонт; $\mathrm{H}_{4} \mathrm{il}$ (88138 см) - гумусово-акумулятивний ілювіальний лесивований глинистий горизонт; Hpil (138-160см) перший перехідний ілювіальний лесивований глинистий горизонт; Philk (160-187 см) - другий перехідний ілювіальний лесивований глинистий горизонт; Pilk (187230 см) - ілювіальний лесивований глинистий карбонатний горизонт делювіальної материнської породи; $\mathrm{P}_{1} \mathrm{k}$ (230-250 см) - глинистий карбонатний горизонт; $\mathrm{P}_{2} \mathrm{k}$ (250-300 см) - глинистий карбонатний горизонт; $\mathrm{P}_{3} \mathrm{k}(300-350 \mathrm{~cm})$ - глинистий карбонатний горизонт.

Лучно-чорноземні грунти (Luvic Gleyic Chernic Phaeozem) в тальвезі (ПП 109-В) формуються на делювіальних гумусованих відкладах важкосуглинкового гранулометричного складу в умовах транзитного атмосферно-грунтового припливно-відпливного зволоження. Тип будови профілю поліциклічний: $\mathrm{H}_{0}(3-0$ см) - лісова підстилка 3 листя і відмерлих трав; $\mathrm{H}_{1} \mathrm{el}$ (0-8 см) поверхневий гумусово-акумулятивний елювіальний лесивований легкосуглинковий горизонт; $\mathrm{H}_{2} \mathrm{el}(8-34$ см) другий гумусово-акумулятивний елювіальний лесивований важкосуглинковий горизонт; $\mathrm{H}_{3} \mathrm{el}$ (34-60 см) - третій гумусово-акумулятивний елювіальний лесивований важкосуглинковий горизонт; $\mathrm{H}_{4} \mathrm{il}(60-118$ см) - гумусовоакумулятивний ілювіальний лесивований важкосуглинковий горизонт; Hpil (118-132 см) - перший перехідний ілювіальний лесивований глинистий горизонт; Phil (132-166 см) - другий перехідний ілювіальний лесивований глинистий горизонт; Ph (166-200 см) - третій перехідний глинистий горизонт; $\mathrm{P}_{1} \quad(200-240$ см) глинистий горизонт; $\mathrm{P}_{2} \mathrm{k}(240-260$ см) - глинистий карбонатний горизонт.

\section{Фрактальні властивості гд/тд відносного розподілу}

Алгоритм вивчення фрактальних властивостей відносного розподілу складається 3 послідовних етапів:
1) виявлення наявності фрактальної структури гд/тд відносного розподілу; 2) визначення рівнів подібності; 3) визначення морфометричних параметрів відносного розподілу на кожному з виявлених рівнів подібності, до яких відносяться гд/тд поріг, розмірність грубої фракції, гд/тд співвідношення. Додатковим параметром $\epsilon$ особливості просторового розподілу грубих часток на кожному з рівнів.

Виділення рівнів подібності фрактальної структури проводиться в різному масштабі, із застосуванням малих $(\times 35)$, середніх $(\times 90)$ і великих $(\times 200)$ збільшень. При малому збільшенні виявляється перший рівень відносного розподілу грубо- та тонкодисперсних часток і проводяться морфометричні вимірювання. На другому етапі, при середніх збільшеннях, досліджується матеріал, віднесений до тонкодисперсного при малих збільшеннях. Визначається гд/тд поріг та інші морфометричні показники. На третьому етапі алгоритм дій повторюється при великих збільшеннях досліджується матеріал, віднесений до тонкодисперсного при середніх збільшеннях.

Як модель багаторівневої подібності гд/тд відносного розподілу в різних масштабах відповідає геометричний фрактал килим Серпинського (рис. 1).
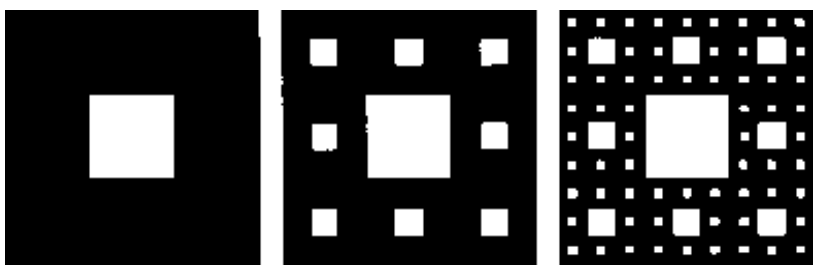

Рис. 1. Кроки побудови килиму Серпинського (Feder, 1991) аналогічні виділенню рівнів подібності відносного розподілу при мікроморфологічних дослідженнях.

Важливо зазначити, що фрактальна структура відносного розподілу виявляється як візуальний образ мікроморфологічної організації, що сполучає в собі кількісну та якісну характеристику твердої фази i не дублює та не розпізнається гранулометричним аналізом, оскільки порогові значення при виділенні конкретного рівня відносного розподілу не пов'язані 3 градаціями фракцій при гранулометричному аналізі (наприклад, класифікації гранулометричних елементів наведені в роботі (Vadyunina, Korchagina, 1986) та в Guidelines for soil description (2006)). 
Комплексна характеристика, отримана в такий спосіб, дозволяе діагностувати літологічну однорідність або неоднорідність профілю і ступінь контрастності останньої (табл. 2).

\section{Чорнозем звичайний (Calcic Chernozem)}

Тип гд/тд відносного розподілу - порфірік. Гд/тд відносний розподіл дослідженого грунту має трирівневу фрактальну структуру (рис. 2). Поріг виділення першого рівня гд/тд відносного розподілу становить 0,15 мм по всьому профілі. Верхня межа розмірності грубодисперсної фракції варіює в різних горизонтах від 0,29 до 0,45 мм. Вміст зерен грубодисперсної фракції незначний, не перевищує $1 \%$. Просторовий розподіл грубих часток нерівномірний, неупорядкований.

Поріг виділення другого рівня гд/тд відносного розподілу дорівнює 0,02 мм по всьому профілю. Основу

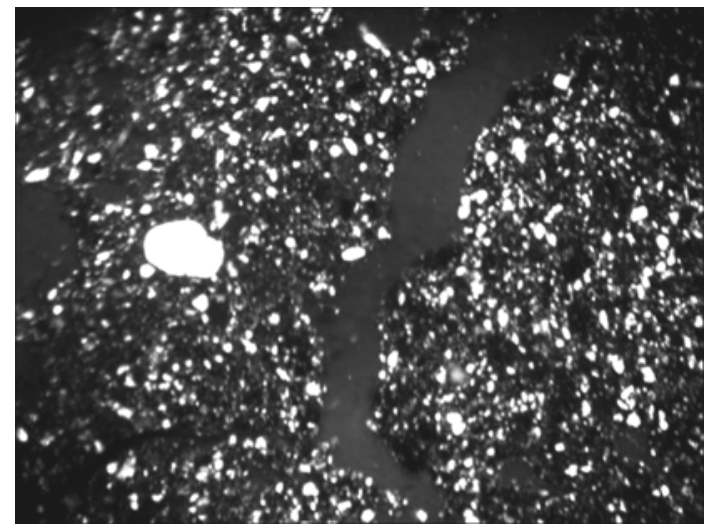

a
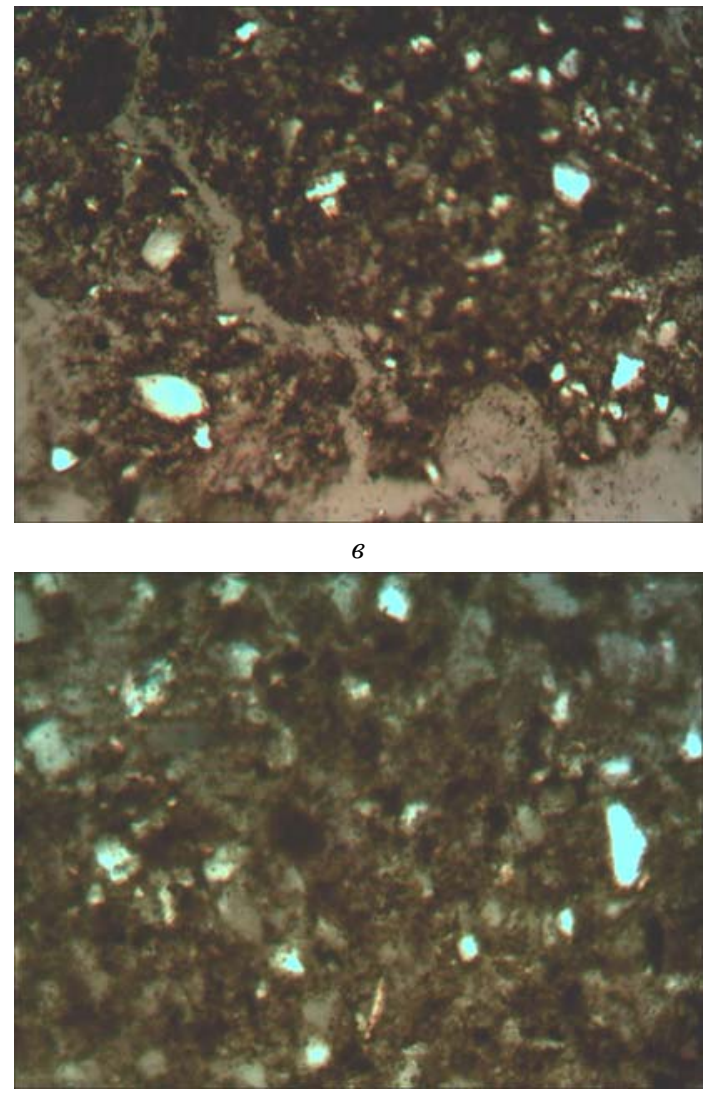

$\partial$ грубодисперсної фракції в грунтових горизонтах становлять зерна розміром $0,02-0,1$ мм, у лесовій материнській породі 0,02-0,09 мм. Вміст грубодисперсних часток у грунтових горизонтах становить $14-15 \%$, у материнській породі - $10 \%$. Просторовий розподіл грубих часток на цьому рівні подібності відносного розподілу характеризується рівномірністю.

Поріг виділення третього рівня відносного розподілу дорівнює 0,005 мм. Основу грубої фракції складають частки розміром $0,005-0,01$ мм як у профілі грунту, так і в материнській породі. Просторовий розподіл грубодисперсних часток рівномірний.

Визначені характеристики гд/тд відносного розподілу грунтових горизонтів і грунтоутворюючої породи свідчать про літологічну однорідність профілю досліджуваних грунтів.
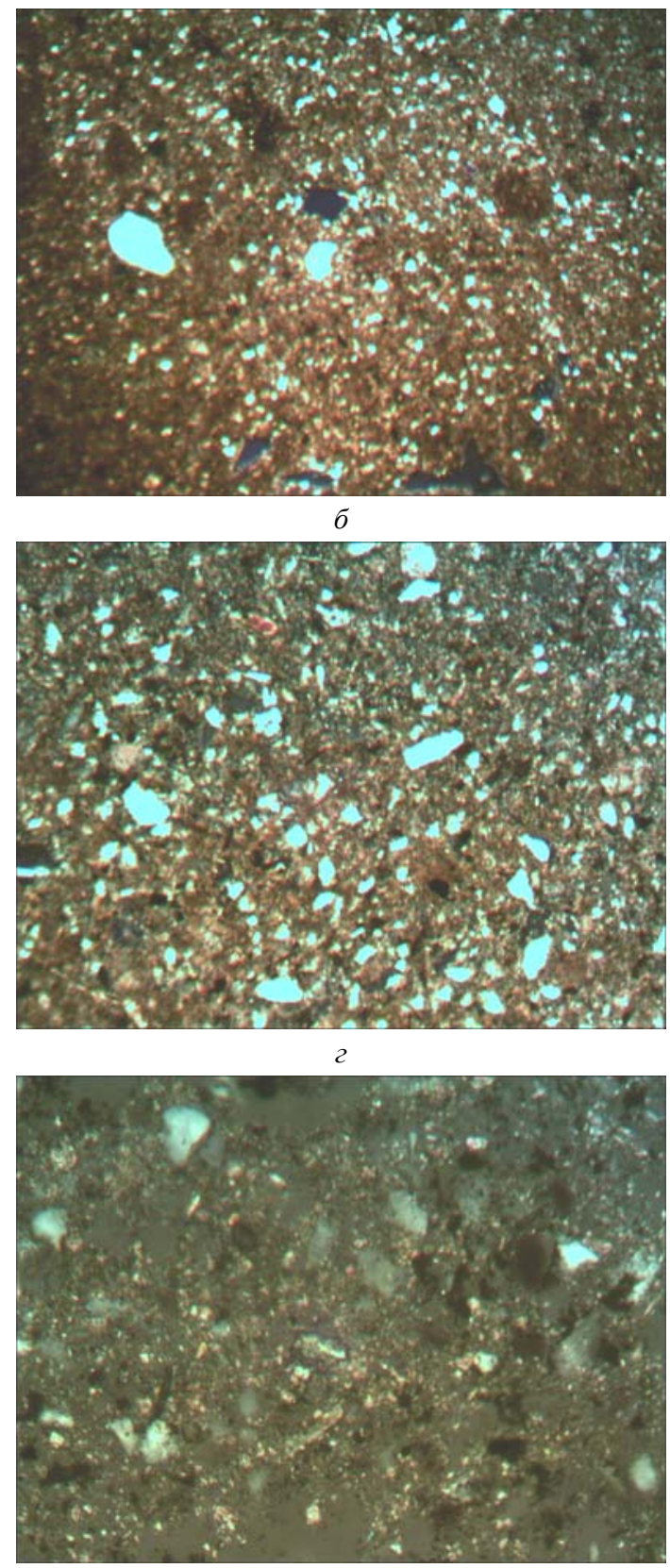

Pис. 2. Фрактальна структура гд/тд відносного розподілу горизонтів $\operatorname{Hpk}(a, b, \partial)$ i $\mathrm{Pk}(\sigma, 2, e)$ у чорноземі звичайному

(Calcic Chernozem). Як у верхній, так і в нижній частині профілю рівні подібності мають однакові значення гд/тд порогу виділення, що відображено на фото. Мікробудова першого рівня показана на рис. $a, \sigma$ (збільшення 35 ,

ширина фотографій 2,47 мм, ніколі схрещені), другого - на рис. в, г (збільшення 90, ширина фотографій 1 мм, ніколі напівсхрещені), третього - на рис. $\partial$, e (збільшення 200, ширина фотографій 0,46 мм, ніколі напівсхрещені). 
Таблиця 2

Характеристика гд/тд відносного розподілу грунтів

\begin{tabular}{|c|c|c|c|c|c|}
\hline $\begin{array}{c}\text { Генетичний } \\
\text { горизонт }\end{array}$ & $\begin{array}{c}\text { Тип гд/тд } \\
\text { відносного } \\
\text { розподілу }\end{array}$ & $\begin{array}{l}\text { Рівні гд/тд } \\
\text { порогу, мм }\end{array}$ & $\begin{array}{c}\text { Грубодисперсні } \\
\text { частки, мм }\end{array}$ & $\begin{array}{c}\text { Гд/тд } \\
\text { співвідношення, \% }\end{array}$ & $\begin{array}{l}\text { Просторовий розподіл } \\
\text { грубодисперсних часток }\end{array}$ \\
\hline \multicolumn{6}{|c|}{ Чорнозем звичайний (Calcic Chernozem) } \\
\hline \multirow{3}{*}{$\operatorname{Hdk}(0-6 \mathrm{~cm})$} & \multirow{3}{*}{ Порфірік } & 0,15 & $0,15-0,45$ & $1: 99$ & Нерівномірний \\
\hline & & 0,02 & $0,02-0,1$ & $14: 86$ & Рівномірний \\
\hline & & 0,005 & $0,005-0,01$ & - & Рівномірний \\
\hline \multirow{3}{*}{ Hpk (6-27 cм) } & \multirow{3}{*}{ Порфірік } & 0,15 & $0,15-0,29$ & Грубих зерен $<1$ & Нерівномірний \\
\hline & & 0,02 & $0,02-0,1$ & $14: 86$ & Рівномірний \\
\hline & & 0,005 & $0,005-0,01$ & - & Рівномірний \\
\hline \multirow{3}{*}{ Phk (27-40 см) } & \multirow{3}{*}{ Порфірік } & 0,15 & $0,15-0,21$ & Грубих зерен $<1$ & Нерівномірний \\
\hline & & 0,02 & $0,02-0,1$ & $15: 85$ & Рівномірний \\
\hline & & 0,005 & $0,005-0,01$ & - & Рівномірний \\
\hline \multirow{3}{*}{$\mathrm{Pk}(40-120 \mathrm{~cm})$} & \multirow{3}{*}{ Порфірік } & 0,15 & $0,15-0,3$ & Грубих зерен $<1$ & Нерівномірний \\
\hline & & 0,02 & $0,02-0,09$ & $10: 90$ & Рівномірний \\
\hline & & 0,005 & $0,005-0,01$ & - & Рівномірний \\
\hline \multicolumn{6}{|c|}{ Чорнозем лісовий (Luvic Chernic Phaeozem) } \\
\hline \multirow{3}{*}{$\mathrm{H}_{1} \mathrm{el}(0-9 \mathrm{~cm})$} & \multirow{3}{*}{ Порфірік } & 0,15 & $0,15-0,52$ & $6: 94$ & Нерівномірний \\
\hline & & 0,02 & $0,02-0,09$ & $3: 97$ & Рівномірний \\
\hline & & 0,005 & $0,005-0,01$ & - & Рівномірний \\
\hline \multirow{3}{*}{$\mathrm{H}_{2} \mathrm{el}(9-46 \mathrm{~cm})$} & \multirow{3}{*}{ Порфірік } & 0,15 & $0,15-0,59$ & $3: 97$ & Нерівномірний \\
\hline & & 0,02 & $0,02-0,09$ & $7: 93$ & Рівномірний \\
\hline & & 0,005 & $0,005-0,01$ & - & Рівномірний \\
\hline \multirow{3}{*}{$\mathrm{H}_{3} \mathrm{el}(46-88 \mathrm{~cm})$} & \multirow{3}{*}{ Порфірік } & 0,1 & $0,1-0,78$ & $2: 98$ & Нерівномірний \\
\hline & & 0,02 & $0,02-0,06$ & $8: 92$ & Рівномірний \\
\hline & & 0,005 & $0,005-0,01$ & - & Рівномірний \\
\hline & & 0,1 & $0,1-0,53$ & $3: 97$ & Нерівномірний \\
\hline $\mathrm{H}_{4} \mathrm{il}(88-138 \mathrm{~cm})$ & Порфірік & 0,02 & $0,02-0,06$ & $8: 92$ & Рівномірний \\
\hline & & 0,005 & $0,005-0,01$ & - & Рівномірний \\
\hline & & 0,1 & $0,1-0,51$ & $2: 98$ & Нерівномірний \\
\hline Hpil (138-160 см) & Порфірік & 0,02 & $0,02-0,06$ & $8: 92$ & Рівномірний \\
\hline & & 0,005 & $0,005-0,01$ & - & Рівномірний \\
\hline & & 0,1 & $0,1-0,45$ & $2: 98$ & Нерівномірний \\
\hline Philk (160-187 см) & Порфірік & 0,02 & $0,02-0,06$ & $8: 92$ & Рівномірний \\
\hline & & 0,005 & $0,005-0,01$ & - & Рівномірний \\
\hline & & 0,1 & $0,1-0,4$ & $3: 97$ & Нерівномірний \\
\hline Pilk (187-230 см) & Порфірік & 0,02 & $0,02-0,06$ & $7: 93$ & Рівномірний \\
\hline & & 0,005 & $0,005-0,01$ & - & Рівномірний \\
\hline & & 0,1 & $0,1-0,45$ & $2: 98$ & - \\
\hline $\mathrm{P}_{1} \mathrm{k}(230-250 \mathrm{~cm})$ & - & 0,02 & $0,02-0,03$ & $8: 92$ & - \\
\hline & & 0,003 & $0,003-0,005$ & - & - \\
\hline & & 0,1 & $0,1-0,6$ & $1: 99$ & - \\
\hline $\mathrm{P}_{2} \mathrm{k}(250-300 \mathrm{~cm})$ & - & 0,02 & $0,02-0,03$ & $8: 92$ & - \\
\hline & & 0,003 & $0,003-0,005$ & - & - \\
\hline & & 0,1 & $0,1-0,45$ & $1: 99$ & - \\
\hline $\mathrm{P}_{3} \mathrm{k}(300-350 \mathrm{~cm})$ & - & 0,02 & $0,02-0,03$ & $10: 90$ & - \\
\hline & & 0,003 & $0,003-0,005$ & - & - \\
\hline & & чно-чорнозем & ий грунт (Luvic Gle & c Chernic Phaeozem) & \\
\hline & & 0,1 & $0,1-0,45$ & $1: 99$ & Нерівномірний \\
\hline $\mathrm{H}_{1} \mathrm{el}(0-8 \mathrm{~cm})$ & Порфірік & 0,02 & $0,02-0,06$ & $10: 90$ & Рівномірний \\
\hline & & 0,005 & $0,005-0,01$ & - & Рівномірний \\
\hline & & 0,1 & $0,1-0,45$ & $5: 95$ & Нерівномірний \\
\hline $\mathrm{H}_{2} \mathrm{el}(8-34 \mathrm{~cm})$ & Порфірік & 0,02 & $0,02-0,06$ & $5: 95$ & Рівномірний \\
\hline & & 0,005 & $0,005-0,01$ & - & Рівномірний \\
\hline & & 0,1 & $0,1-0,57$ & $5: 95$ & Нерівномірний \\
\hline $\mathrm{H}_{3} \mathrm{el}(34-60 \mathrm{~cm})$ & Порфірік & 0,02 & $0,02-0,06$ & $5: 95$ & Рівномірний \\
\hline & & 0,005 & $0,005-0,01$ & - & Рівномірний \\
\hline & & 0,1 & $0,1-0,7$ & $7: 93$ & Нерівномірний \\
\hline $\mathrm{H}_{4} \mathrm{il}(60-118 \mathrm{~cm})$ & Порфірік & 0,02 & $0,02-0,06$ & $6: 94$ & Рівномірний \\
\hline & & 0,005 & $0,005-0,01$ & - & Рівномірний \\
\hline & & 0,1 & $0,1-0,38$ & $2: 98$ & Нерівномірний \\
\hline Hpil (118-132 см) & Порфірік & 0,02 & $0,02-0,06$ & $8: 92$ & Рівномірний \\
\hline & & 0,005 & $0,005-0,01$ & - & Рівномірний \\
\hline
\end{tabular}


Чорнозем лісовий (Luvic Chernic Phaeozem)

Тип гд/тд відносного розподілу - порфірік. Грунти на схилі байраку також характеризуються трирівневою фрактальною структурою відносного розподілу часток (рис. 3).

Поріг виділення першого рівня становить 0,15 мм по всьому профілю. Верхня межа розмірності грубодисперсної фракції варіює за горизонтами від 0,4 до 0,78 мм. Вміст грубодисперсних часток коливається від 2 до $6 \%$ у грунтових горизонтах та 1-2\% у підгрунтових горизонтах $\mathrm{P}_{1} \mathrm{k}, \mathrm{P}_{2} \mathrm{k}$ i $\mathrm{P}_{3} \mathrm{k}$. Просторовий розподіл зерен грубої фракції нерівномірний, неупорядкований.

Поріг виділення другого рівня становить 0,02 мм по всьому профілю. У поверхневих горизонтах $\mathrm{H}_{1} \mathrm{el}$ та $\mathrm{H}_{2} \mathrm{el}$ основу грубодисперсної фракції складають зерна розміром 0,02-0,09 мм. У наступних горизонтах включно 3 горизонтом Pilk - 0,02-0,06 мм. Розмір грубодисперсної
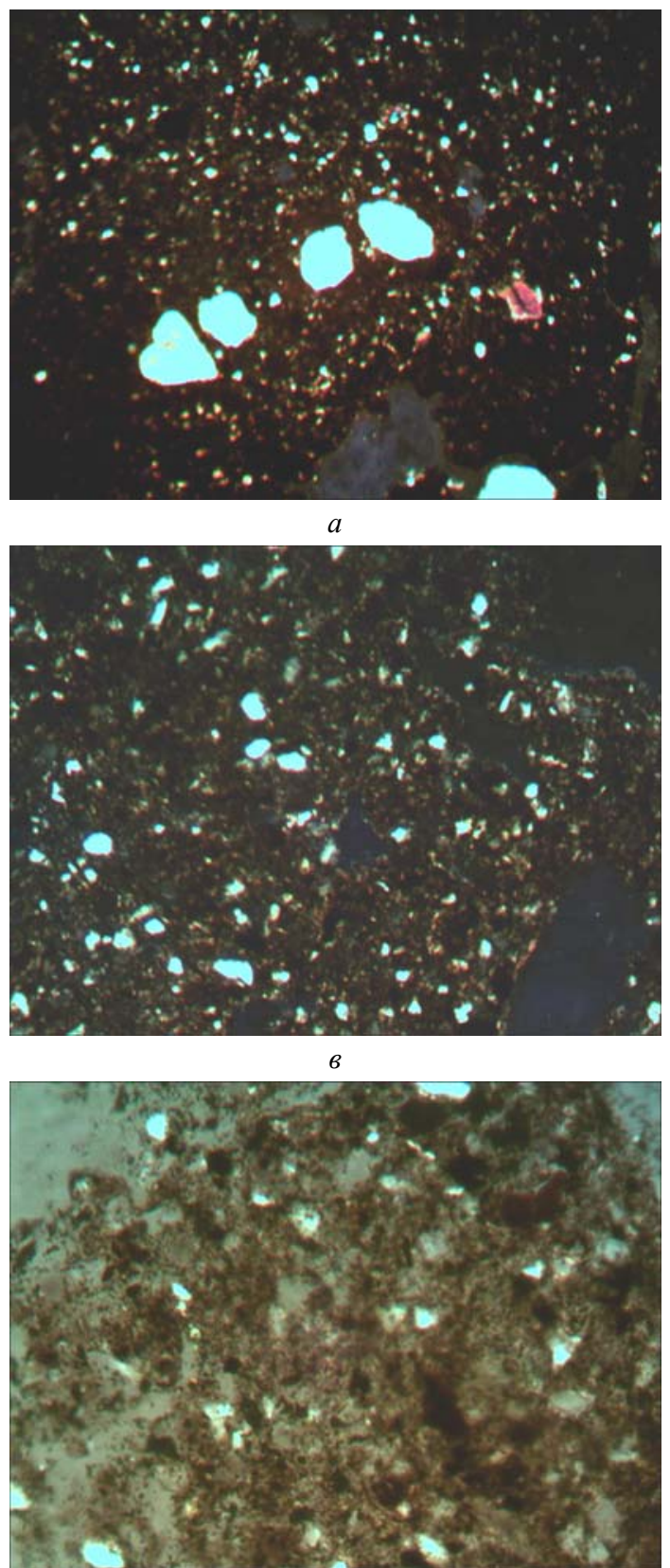

$\partial$ фракції в підгрунтових горизонтах 0,02-0,03 мм. Вміст часток найменший у поверхневому горизонті - $3 \%$, найбільший у горизонті $\mathrm{P}_{3} \mathrm{k}-10 \%$. Профіль у цілому характеризується вмістом грубої фракції на рівні 7-8\%. Просторовий розподіл зерен рівномірний.

Поріг виділення третього рівня становить 0,005 мм для грунтових горизонтів, включно 3 горизонтом Pilk, та 0,003 мм для підгрунтових горизонтів. Грубодисперсну фракцію складають частки розміром $0,005-0,01$ мм у профілі грунту разом з горизонтом Pilk та $0,003-0,005$ мм у підгрунтових горизонтів $\mathrm{P}_{1} \mathrm{k}, \mathrm{P}_{2} \mathrm{k}$ i $\mathrm{P}_{3} \mathrm{k}$. Просторовий розподіл часток грубої фракції рівномірний.

Отримані результати свідчать про літологічну однорідність у межах генетичного профілю грунтів і зміну характеристик у підгрунтових горизонтах $\mathrm{P}_{1} \mathrm{k}, \mathrm{P}_{2} \mathrm{k}$ i $\mathrm{P}_{3} \mathrm{k}$ за показниками другого та третього рівнів подібності гд/тд відносного розподілу.

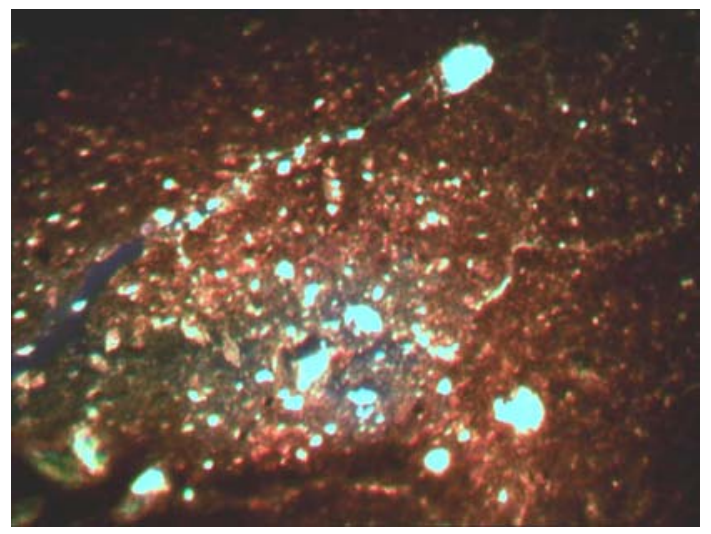

$\sigma$
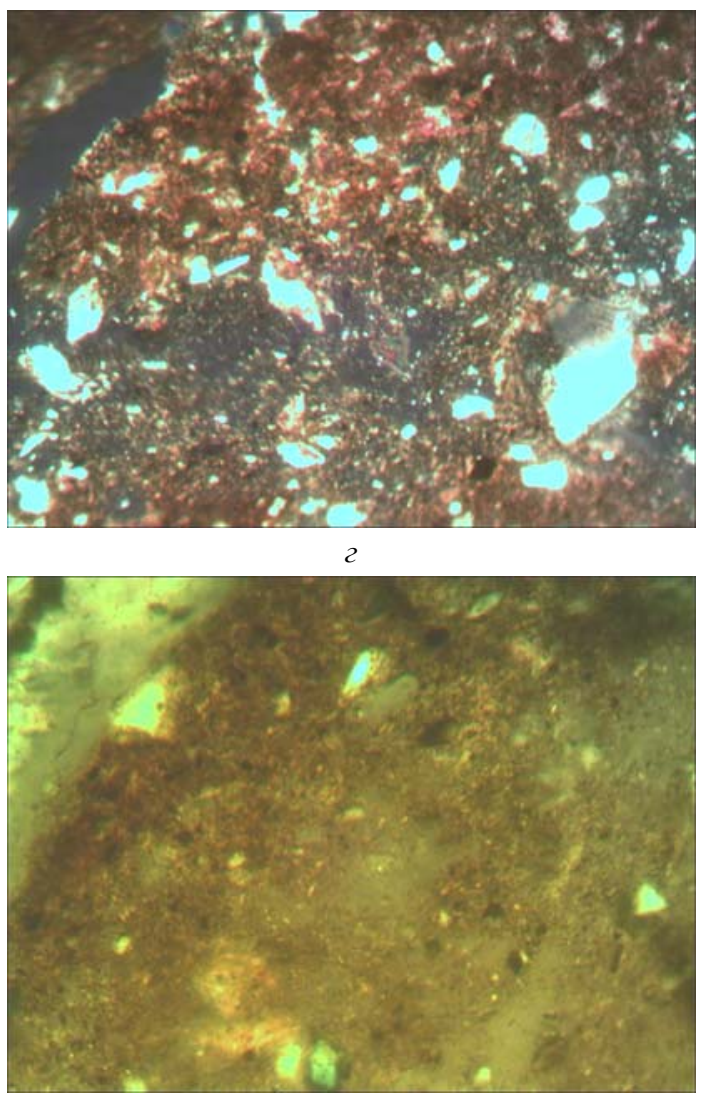

$e$

Рис. 3. Фрактальна структура гд/тд відносного розподілу горизонтів $\mathrm{H}_{2} \mathrm{el}(a, b, \partial)$ i $\mathrm{P}_{1} \mathrm{k}(\sigma, 2, e)$ в чорноземі лісовому

(Luvic Chernic Phaeozem). Підгрунтові горизонти порівняно з грунтовим профілем мають відмінні показники на другому і третьому рівнях подібності відносного розподілу. Картину мікробудови на першому рівні ілюструє pис. $a, \sigma$ (збільшення 35 , ширина фотографій 2,47 мм, ніколі схрещені), другому - рис. 6,2 (збільшення 90 , ширина фотографій 1 мм, ніколі напівсхрещені), третьому - рис. $\partial, e$ (збільшення 200, ширина фотографій 0,46 мм, ніколі напівсхрещені). 


\section{Лучно-чорноземний грунт \\ (Luvic Gleyic Chernic Phaeozem)}

Тип гд/тд відносного розподілу подібно до попередніх грунтів - порфірік. У мікробудові лучно-чорноземних грунтів виділяються три рівні подібності відносного розподілу часток (рис. 4), подібно до чорноземів звичайних і чорноземів лісових.

Поріг виділення першого рівня гд/тд відносного розподілу становить 0,1 мм по всьому профілю. Верхня межа грубодисперсної фракції по профілю коливається від 0,38 до 0,7 мм. Вміст грубодисперсних зерен коливається від 1 до 7 \%. Просторовий розподіл зерен нерівномірний, неупорядкований.
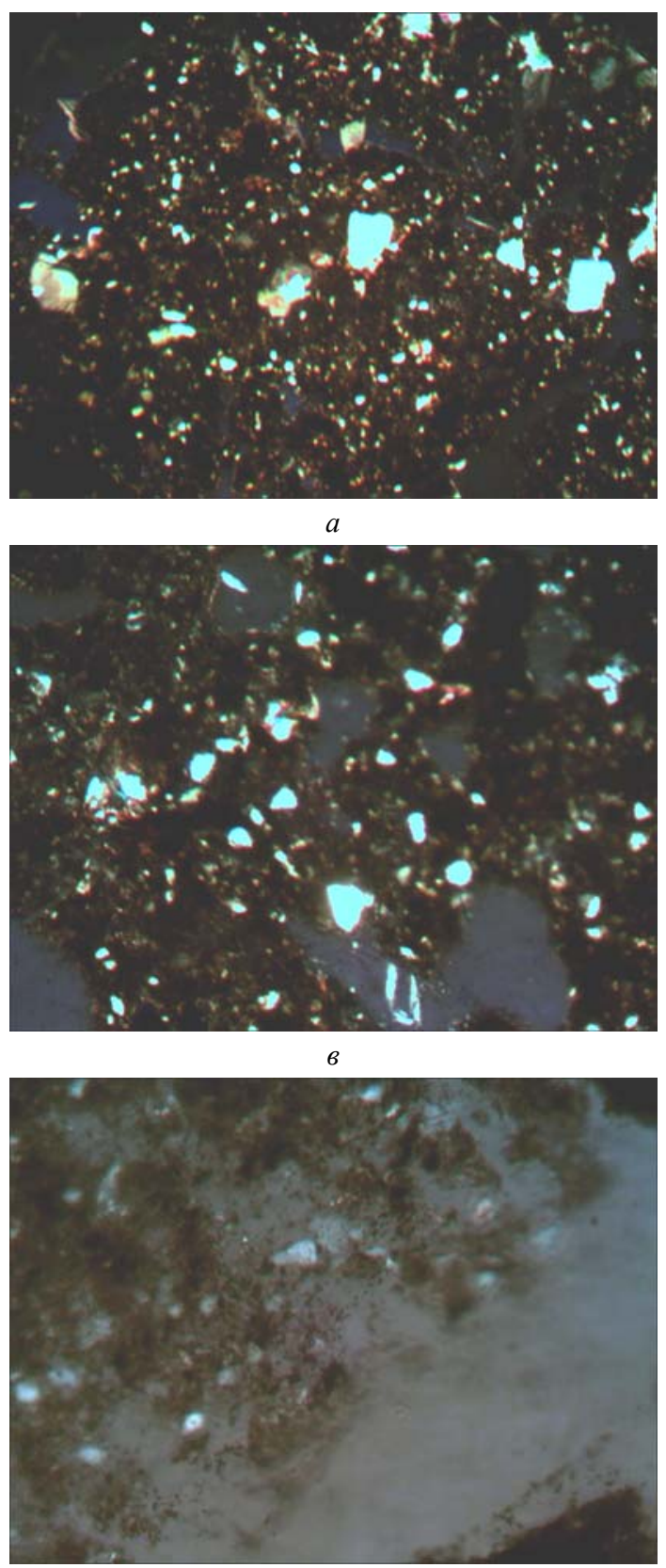

Поріг виділення другого рівня по всьому дослідженому профілю становить 0,02 мм. Основна частина грубих зерен на даному рівні відноситься до фракції 0,02-0,06 мм по всьому профілю. Вміст зерен коливається від 5 до $10 \%$ у різних горизонтах. Просторовий розподіл зерен рівномірний.

Поріг виділення третього рівня дорівнює 0,005 мм по всьому профілю. Складається грубодисперсна частина з часток переважно розміром $0,005-0,01$ мм. Просторовий розподіл грубодисперсної частини в грунтовому матеріалі рівномірний.

Визначені параметри фрактальної структури свідчать про літологічну однорідність дослідженої частини профілю грунтів тальвегу, сформованих на надпотужних делювіальних гумусованих суглинках.

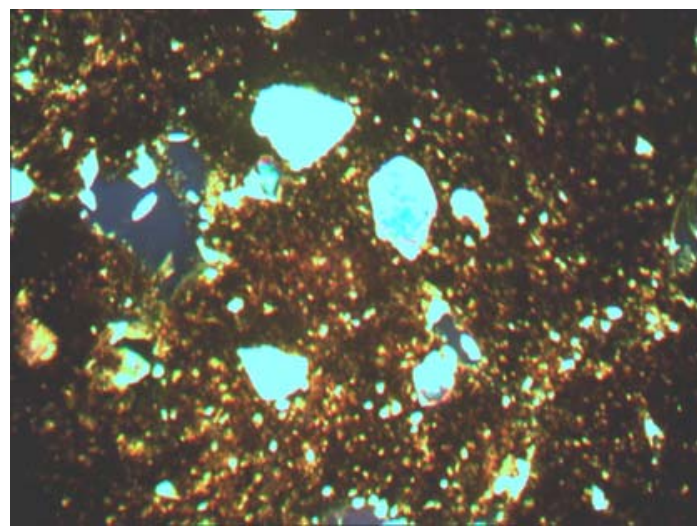

6

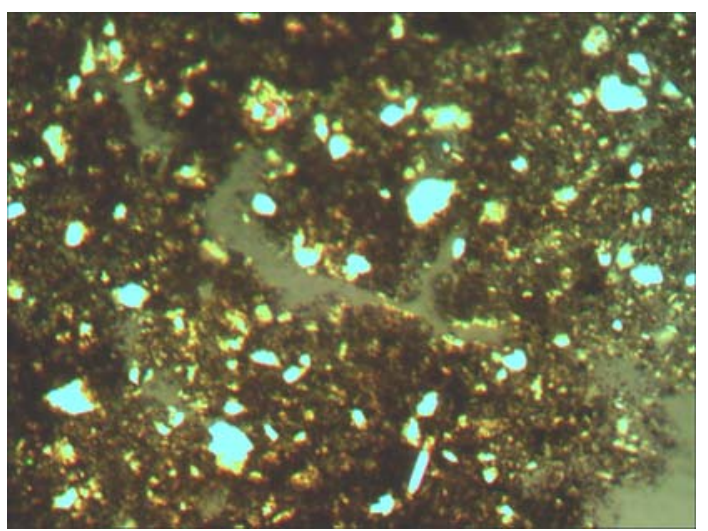

2

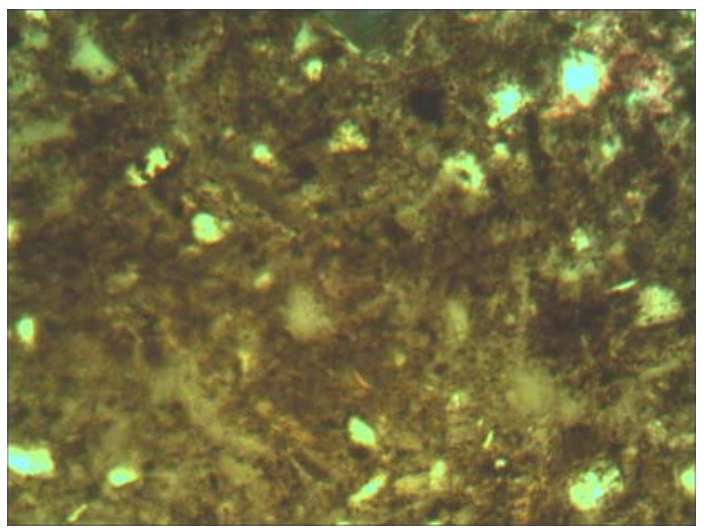

$e$

Рис. 4. Фрактальна структура гд/тд відносного розподілу горизонтів $\mathrm{H}_{2} \mathrm{el}(a, b, \partial)$ i Hpil $(\sigma, 2, e)$ в лучно-чорноземному грунті (Luvic Gleyic Chernic Phaeozem). Параметри виділення і мікробудова рівнів подібності $є$ незмінними на всю потужність дослідженої частини профілю. Перший рівень - рис. $a, \sigma$

(збільшення 35, ширина фотографій 2,47 мм, ніколі схрещені), другий - рис. в, г (збільшення 90, ширина фотографій 1 мм, ніколі напівсхрещені), третій - рис. $\partial$, e (збільшення 200, ширина фотографій 0,46 мм, ніколі напівсхрещені). 


\section{Висновки}

При мікроморфологічному дослідженні грунтів, сформованих на материнських породах суглинкового та глинистого гранулометричного складу, виявляється фрактальна структура відносного розподілу грубо- та тонкодисперсних часток, що сполучає в собі кількісну та якісну характеристику твердої фази і не розпізнається гранулометричним аналізом.

Дослідження фрактальних властивостей гд/тд відносного розподілу дає можливість діагностувати літологічну неоднорідність генетичного профілю грунтів та проводити поетапне встановлення контрастності такої неоднорідності.

Досліджені лісові грунти Присамар'я характеризуються трирівневою фрактальною структурою організації відносного розподілу гранулометричних елементів мікробудови. На кожному з рівнів відносного розподілу картина мікробудови подібна до рівнів, виділених в інших масштабах.

Грунтові горизонти генетичних профілів чорнозему звичайного, чорнозему лісового та лучно-чорноземного грунту мають подібні фрактальні властивості і морфометричні характеристики гд/тд відносного розподілу. Літологічна подібність мікроморфологічної організації, імовірно, зумовлена генетичними зв'язками грунтів дослідженої катени внаслідок делювіальних процесів.

Чорноземи звичайні поруч 3 узліссям характеризуються літологічною однорідністю профілю i підгрунтових горизонтів лесової материнської породи. Натомість чорноземи лісові на схилі байраку літологічно неоднорідні. Виявлено, що підгрунтові горизонти за межами генетичного профілю грунту відрізняються за морфометричними показниками на другому та третьому рівнях відносного розподілу грубо- та тонкодисперсних часток.

\section{References}

Bozhokin, S. V., Parshin, D. A., 2001. Fraktaly i multifraktaly [Fractals and multifractals]. Regular and chaotic dynamics. Izhevsk (in Russian).

Dobrovolsky, G. V., 1983. Metodicheskoe rukovodstvo po mikromorfologii pochv [Methodological guide to soil micromorphology]. MSU, Moscow (in Russian).
Feder, E., 1991. Fraktaly [Fractals]. Mir, Moscow (in Russian).

Gagarina, E. I., 2004. Mikromorfologicheskij metod issledovaniia pochv [Micromorphological method for studying soil]. St. Petersburg University Press, St. Petersburg (in Russian).

Gerasimova, M. I., Gubin S. V., Shoba S. A., 1992. Mikromorfologiia pochv prirodnuh zon SSSR [Micromorphological features of the USSR zonal soils]. Pushchino Research Center of the Russian Academy of Sciences, Pushchino (in Russian).

Guidelines for soil description. 4th edition (2006) FAO, Rome.

IUSS Working Group WRB. 2015. World Reference Base for Soil Resources 2014, update 2015 International soil classification system for naming soils and creating legends for soil maps. World Soil Resources Reports No. 106. FAO, Rome

Mandelbrot, B. B., 1982. The fractal geometry of nature. Freeman, New York

Morozov, A. D., 2002. Vvedenie v teoriy fraktalov [Introduction to the theory of fractals]. Institute of Computer Science, Izhevsk (in Russian)

Parfyonova, E. I., Yarilova, E. A., 1977. Rukovodstvo k mikromorfologicheskim issledovaniiam $\mathrm{v}$ pochvovedenii [A guide to the micromorphological studies in soil science]. Nauka, Moscow (in Russian).

Rozanov, B. G., 2004. Morfologiia pochv [Morphology of soils]. Academic Project, Moscow (in Russian).

Stoops, G., 2003. Guidelines for Analysis and Description of Soil and Regolith Thin Sections.

Madison, WI, Soil Science Society of America.

Travleev, L. P., 1977. Osobennosti lokalnogo uvlazhneniia edafotopov $\mathrm{v}$ bajrachnykh lesakh i ikh geologogidrologicheskaiia kharakteristika [Features local humidification edaphotopes gully in the woods and their geological and hydrological characteristics]. Questions steppe forest science and environment, 7, 31-39 (in Russian).

Vadyunina, A. F., Korchagina, Z. A., 1986. Metody issledovaniia fizicheskikh svojstv pochvy [Methods of study of the physical properties of soil]. Moscow (in Russian).

Yakovenko, V. M., 2014. Vplyv delyuvialnykh protsesiv na macro- ta mikromorfologiyu bairachnykh lisovykh gruntiv [The influence of deluvial processes on macro- and micromorphology of ravined forest soil]. Gruntoznavstvo, 15(3-4), 74-88 (in Ukrainian).

Yakovenko V. M., Bilova N. A. 2015. Morfologia lisovogo bairachnogo gruntoutvorenny na delyuvialnykh syglunkakh [Morphology of forest ravined soil formation on deluvial loams]. Gruntoznavstvo, 16(3-4), 3-17 (in Ukrainian). 